\title{
The Role of Broadband in Spurring Innovations in Kenya
}

\author{
Article by Philip Muchiri ${ }^{1}$ and Simon Karume ${ }^{2}$ \\ ${ }^{1}$ PhD Computer Science, Texila American University, Guyana \\ ${ }^{2}$ Associate Professor, Laikipia University, Kenya \\ E-mail: philipmuchiri2014@gmail.com
}

\begin{abstract}
Objective: This study attempts to establish the role broadband plays in spurring innovations in Kenya. It discusses the importance of innovations in socio-economic development and the need for a regulatory framework to improve broadband infrastructure developments in Kenya.

Background: In the last few years, Kenya has experienced an increase in the number of ICT enabled innovation hubs (Tech Hubs). Although they are few in number and generally not popular, there is great potential for broadband-based innovations in Kenya. The government has also invested heavily in broadband provision. Most of the innovations witnessed in Kenya are broadband enabled. There is need to provide policy, legal and regulatory environment to enable these innovations to flourish. The National Innovation System is the framework adopted for the study.

Methodology: The study utilizes the dimensions of the Kenya National Innovation System as a basis of assessing the role of broadband in spurring innovation in Kenya. A descriptive quantitative study is adopted for this research. Data was collected from existing records, literature review and through interviews. Descriptive statistics were used to analyse the data.

Results: There is a relationship between broadband diffusion and innovations development in Kenya. Broadband plays an important role in spurring innovations. Regulatory environment is vital in broadband infrastructure development in order to encourage innovations.

Conclusion: The government should put in place policies and mechanisms to encourage innovations. Collaboration, investments in research and development should be encouraged between private and public institutions. A more detailed study on broadband enabled innovation is recommended for each sector of the economy.
\end{abstract}

Keywords: Broadband, Innovations, Policy, Innovation Hubs, Start-ups, National Innovation System (NIS)

\section{Introduction}

It is important to have an effective National Innovation System(NIS) in order to harness innovation and accelerate development in Kenya. This was recognized by the Government of Kenya through the ministry of Science and Technology. It therefore developed an innovation policy document known as the Science, Technology and Innovation policy and strategy in March 2008[1] to enable the achievement of vision 2030. The aim of this policy and strategy was to harness collective talents and creativity of Kenyans in order to promote capacity building. This was to be achieved through human, financial and infrastructural developments and creation of effective networking and linkages to enable generation and sharing of knowledge. The strategy also proposed the creation of an enabling environment for the application of these skills in production and innovation as well as opportunities for technological learning particularly within industry and business enterprises. Information Communication Technology (ICT) was identified as an important sector in the achievement of national growth and development targets. It proposed provision of a robust ICT infrastructure to stimulate and support local ICT industry growth and improve service delivery in both public and private sectors. 
The aim of this study therefore is to do a follow-up and fast-track the achievements since the launch of this strategy eight years later. This is done by analyzing the role of broadband (an important ICT infrastructure) in spurring innovations in Kenya.

In the last few years Kenya has experienced growth in the number of innovations as well broadband infrastructural developments. The paper tries to establish the relationship between this broadband infrastructural development and innovation. It begins by studying the historical developments in broadband and the growth in the number of tech/innovation hubs, incubators and start-up companies. An analysis of the role played by the government of Kenya in broadband utilization to spur innovation is conducted. A descriptive study is adopted for this research. Data is collected from existing records, literature review and through interviews. Identification of the measurement metrics to assess the Kenya National Innovation System (KNIS) is done. Using these metrics, data is collected from knoema.com website [2]. Knoema.com is a website that collects statistics from international organizations such as the World Bank, International Telecommunications Union (ITU), International Monetary Fund (MF), Central Intelligence Agency (CIA) as well as from local organizations such as the Kenya Bureau of statistics and organizes it under country main indicators. Finally, this study presents the results of data analysis in tables, charts, and graphs before drawing a conclusion and policy recommendations.

\section{Background of the research}

Kenya is classified as a low income country found in the eastern African region. In the global competitiveness ranking, it is ranked number 92 out of 140[3][4]. It has a population of 45.5million, GDP equal to 60.8 billion USD and a GDP per capita of 1,903.4[5]. Kenya's geographical position, socio-economic, multi-cultural society and political status play an important role in global competitiveness and innovation.

Many scholars have made an explicit connection between broadband and the ability of firms to innovate [6][7][8]. Czernich et al. (2009) observes that the emergence of telecommunications infrastructure and high-speed internet enables the creation of new business and firm-cooperation models that boosts innovation processes.

Broadband is a high data transmission network offering a combined speed of $256 \mathrm{kbps}$ or greater for both downstream and upstream connections [9][10]. It may also include mobile broadband and portable internet. Broadband connections use satellite, telephone lines, optical fibres, the cable TV network, power lines or mobile networks to reach the internet.

According to [11], innovation has been defined as the production, exploitation and assimilation of a novelty in economic and social setup. Others define it as the enlargement and renewal of services, products and markets. It is also seen as the development and application of novel methods of production and establishment of new management procedures. In all these definitions it is seen as both a process and an output. This study recognizes and acknowledges these definitions and in addition extends the definition of innovation as having a socio-economic impact to the citizens of a country such as Kenya. It studies innovation in the context of broadband. Many empirical studies/research and firm surveys show that innovation leads to new products and services with high quality and low in price.

\section{The national innovation system (NIS)}

A National Innovation System (NIS) is the framework in the basis of which governments formulate and implement policies that directly influences the innovation process in a country. The framework creates a system of interconnected institutions which individually and jointly contribute to the development and diffusion of new technologies[12]. NIS is an important conceptual framework that can be used to analyse the knowledge system in which innovation occurs. Figure 1 shown below illustrates the conceptual framework of NIS showing all the actors and activities in the economy which are necessary for innovation to take place and lead to economic development[13]. 


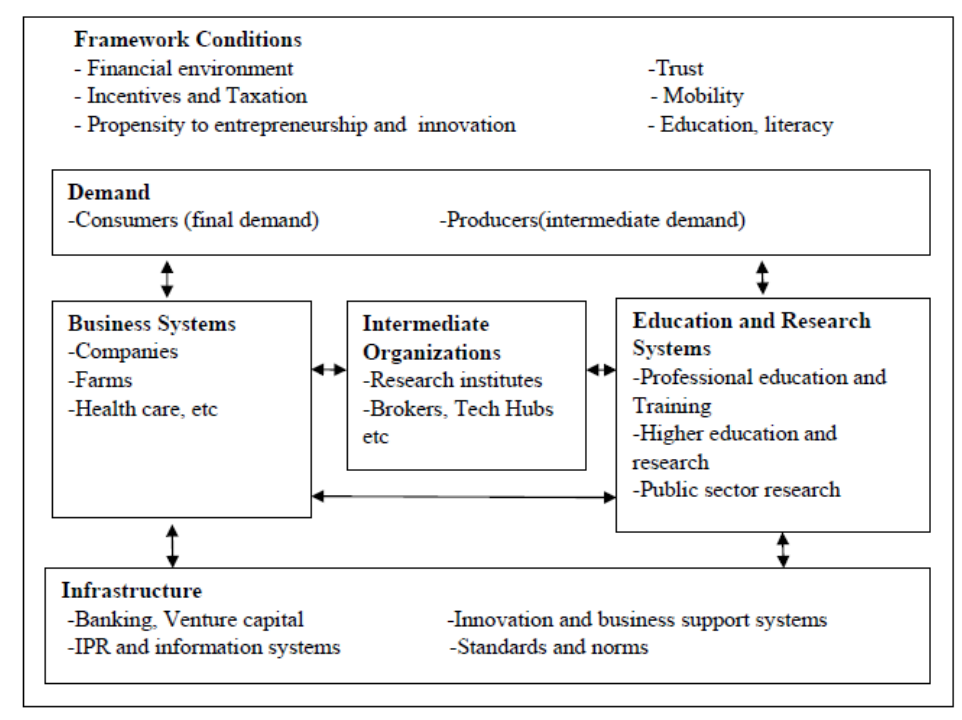

Figure 1: The main Components of NIS

Source: Kenya Science, Technology and Innovation Policy and Strategy Paper, March 2008., Arnold and Bell, 2001

The framework shows that the capacity of an enterprise or individual to engage in innovation may depend on many factors. It may depend on access to knowledge and technology from research institutes or technology Hubs, access to finance such through banking, micro-credit providers and venture capital, provision of adequate human resource, availability of basic physical infrastructure such as broadband, electricity and transport, firmlevel capabilities, inter-firm linkages and collaboration, general business services and innovation support, demand conditions as well as framework conditions such as investment climate, culture of entrepreneurship and basic literacy. Innovation therefore, is not concentrated within a single institution but operates within and among the interacting actors in the innovation system[14]. The Kenya National Innovation System (KNIS) proposed in the Science, Technology and Innovation policy and strategic document is a framework where science, technology and innovation infrastructure interact dynamically and respond to national needs by adopting a system approach that addresses innovation dynamism in all sectors of the economy by examining their interdependency, interconnections, and interrelations. Below is the detailed analysis of how the government of Kenya has attempted to realize the aspiration of KNIS.

\section{Demand and competition}

The Kenya National Innovation System's Policy Strategy of 2008[1], aimed at putting in place a well functioning innovation system that ensures enhanced competitiveness with the hope that pressure of competition will drive firms to demand better skills and knowledge. The effect of this would be diffusion of innovation across all sectors leading to increased production. Competition is healthy in any business environment. It encourages adoption of more sophisticated methods of operation and service delivery in order to have a competitive edge from other business rivalries. Universities compete amongst themselves to increase enrolments in order to improve their capital base. They achieve this by increasing the number of programs they offer as well as improve the quality of services they provide. Competition also arises among technologies and among broadband Internet service providers. Technologies competing for broadband provision in kenya include; satellite, Digital Subscriber Line((DSL), cable mode provision and wireless. Broadband internet service providers operating in Kenya include safaricom, orange Telkom, airtel and essar. Others include Jamii Telecom, liquid Telcom, access Kenya Group, Kenya Education Network (KENET), Wananchi Group, Internet solutions and MTN. Competition brings down the costs 
of broadband, improves broadband penetration levels as well as the quality standards of services delivered leading to innovation. This has the effect of encouraging foreign investments, boost employment and better salaries as well as create incentives that encourage intellectual property protection laws. This lead to formulation of the following research question:

What is the impact of broadband competition on innovation in Kenya?

\section{Education and research}

There is a growing demand for broadband internet at the institutions for higher learning for service expansion, new services creation and product innovations. Broadband internet infrastructure can contribute to business expansion, product innovation, and new business creation [15]. The collaborative innovation network formation through fixed and mobile broadband infrastructure provide necessary platforms through which ideas that are critical to innovation can be shared[16]. Technological innovation is changing the way in which universities teach and students learn. Access to distant education, use of sophisticated learning and teaching management systems and the desire to collaborate with research partners and other industry players are transformational benefits that universities are experiencing.

There are numerous uses in which broadband is utilized by universities to be innovative. Administrators use broadband to deliver tools and services for use by students and educators. Course management platforms are used for the creation of online learning environments and facilitating the administration of education processes. Provision of open content on the Web enables access to educational information. Online learning is made possible through provision of broadband. Mobile learning utilizes handheld devices for teaching and learning purposes. Broadband enables research through access to research material, publication journals and other data repositories. Table 1 below summarises the uses and impacts of broadband for innovation purpose.

Table 1: Uses and impacts of BI for innovation

\begin{tabular}{|l|l|l|}
\hline Users & Uses & Impacts \\
\hline Educators & $\begin{array}{l}\text { Access critical curricular \& } \\
\text { professional development } \\
\text { resources, Participate in } \\
\text { professional development, } \\
\text { Planning, Web 2.0 tools }\end{array}$ & $\begin{array}{l}\text { Enhanced curricula, Resource } \\
\text { sharing, Increased effectiveness, } \\
\text { More interactive classrooms }\end{array}$ \\
\hline $\begin{array}{l}\text { Administrative } \\
\text { purposes }\end{array}$ & $\begin{array}{l}\text { Streamline back office functions, } \\
\text { Outsource data processes, } \\
\text { Aggregate, store, and analyze } \\
\text { student data }\end{array}$ & $\begin{array}{l}\text { Enhanced efficiency in } \\
\text { completing tasks, Cost savings by } \\
\text { moving to cloud computing, More } \\
\text { collaboration }\end{array}$ \\
\hline Students & $\begin{array}{l}\text { Gaming, Online learning, Blended } \\
\text { learning, Mobile learning }\end{array}$ & $\begin{array}{l}\text { Increased number of learning } \\
\text { environments, Enhanced } \\
\text { opportunities for disabled } \\
\text { students, Personalized instruction, } \\
\text { Enhanced learning outcomes and } \\
\text { skill development }\end{array}$ \\
\hline
\end{tabular}

Source: Charles M. Davidson Michael J. Santorelli. A report to U.S Chamber of commerce 2010 on the impact of broadband on education

The following research questions form the basis of this study:

Do institutions of learning play any role in broadband utilization for innovation in the education sector? And What is the role of education in broadband based innovation in Kenya? 


\section{Intermediate organizations}

Technology scene in Kenya has grown rapidly over the last ten years. The emergence of technology hubs, broadband penetration, government broadband policy and support has played an important role in innovative activities of firms, SMEs, and individuals. Mlab East Africa, iHub, Nailab, Emobilis, Growth Hub amongst many technology hubs and accelerators have proved to be great initiatives in terms of accelerating innovation in the country. They achieve this through accelerator programs, incubation centres, ideation programs, hackathons, entrepreneurial coaching, networking and collaborations. The education sector has also followed suite whereby institutions like Strathmore, Kenyatta and Nairobi Universities have also set up hubs within their campuses to enhance innovation. Strathmore University for instance put in place the ilab, Nairobi University set up C4D lab while Kenyatta university introduced the Digital learning program where students are provided with tablets to enable them study anywhere at any time. The government has also made major strides in pushing for innovation through the Information and Communications Technology(ICT) Board. It introduced Digital services, Projects initiatives and research documents that have shaped broadband penetration in Kenya. Some of the most notable are National Optic Fibre Broadband Infrastructure (NOFBI), the Kenya Open Data Initiative (KODI), County Connectivity Project (CCP), Digital Villages such as Pasha, Tandaa Grants, Huduma Centres, Communication Authority of Kenya ICT reports and the vision 2030 Konza Technology Park. The Government is collaborating with major industry players like IBM Research lab, KITOs, NASSCOM, Oracle, SAP and Huawei in order to focus on technology trends in the mobile development and provide mentorship sessions for upcoming mobile application developers through incubated start-ups.

This study seeks to answer the following questions:

What is the role of technology Hubs in spurring innovation?

What role does the government of Kenya play in innovative activities?

\section{Broadband infrastructure}

Broadband infrastructure is the foundation upon which innovative activities thrive. It encompasses a comprehensive array of factors such as intellectual property rights, information systems, telecommunications, banking, venture capital, standards and norms, innovation and business support system issues. Innovation, science and technology are critical in addressing infrastructure challenges.

For a long time Kenya and its neighbouring countries relied on satellite and dialup connections for international communication. The landing of four undersea fibre cables in 2009 signified a paradigm shift in both local and international communications. The East African Marine Systems (TEAMS), East Africa Sub-marine Cable System(EASSY), Lower Indian Ocean Network (LION) and SEACOM connect the country to the international broadband highway. Due to its geographical location along the coastal strip of the Indian ocean, Kenya acts as the gateway to other countries. The National Optic Fibre Backbone Infrastructure (NOFBI) connects major cities to this highway. Figure 2 below shows how Kenya is connected to this international broadband highway. Although a large part of the country is still unconnected, other players in the private sector are also busy building broadband infrastructure.

Government Common Core Network (GCCN) architecture improve public access to Government services through integrating work processes, database sharing, improving the flow and exchange of information[17]. Figure 3 below shows the GCCN architecture of database sharing between Government core service providers through NOFBI. A disaster recovery facility initiated by the government for data and systems ensures that the Government services continue to be provided uninterrupted. The facility will also enable County Governments to offers services through cloud computing.

Apart from the Government, the private sector plays an important role in broadband infrastructure deployment. Competition between mobile telecommunications providers 
(Safaricom, Airtel, Orange Telkom and Essar) has resulted in rural broadband penetration. Other large data infrastructure operators such as Jamii Telecom, Access Kenya Group, Wananchi Group, Kenya Education Network(KENET), Liquid Telcom, MTN and Internet Solutions have also improved broadband deployment leading to a relative reduction of tariffs and increased use in mobile and internet broadband. This study seeks to answer the following questions:

What is the state of broadband infrastructure in Kenya?

What role does broadband infrastructure play in enabling innovation in Kenya?

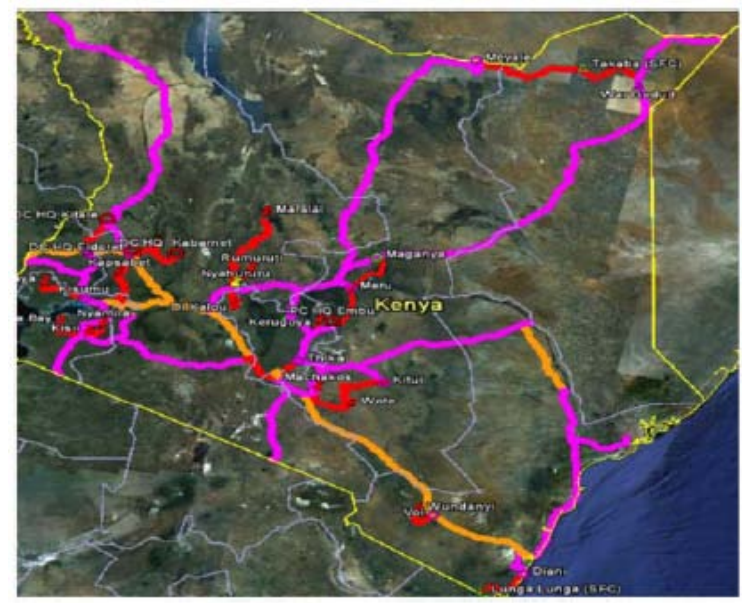

Figure 2. NOFBI Coverage

Source: Kenya National Broadband Master Plan, 2014

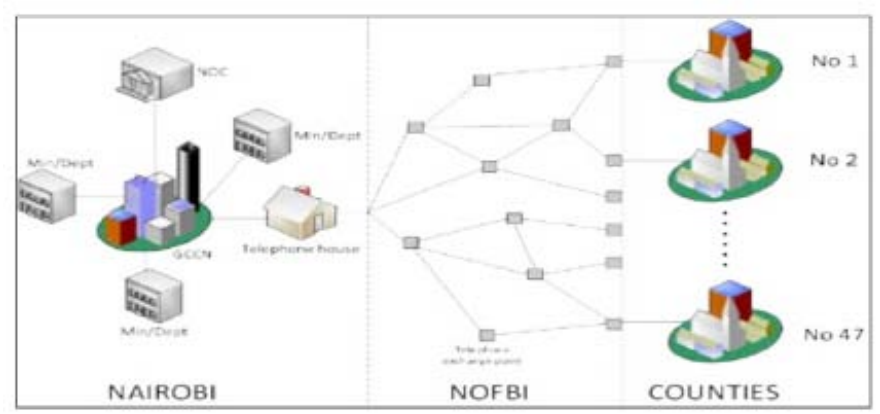

Figure 3. Government Common Core Network (GCCN) Architecture

Source: Kenya National Broadband Master Plan, 2014

\section{Framework conditions}

These are regulatory and facilitative environments that enable the performance of national innovation systems by providing rules that govern research collaboration, commercialisation, research financing, intellectual property rights and researcher mobility among others. These factors are closely linked to culture. The Government of Kenya has instituted fiscal and taxation measures to support innovation but they have not been effective due to lack of a comprehensive national innovation system. Levels of trust in business dealings are low and hinder innovation activities. In addition, low levels of awareness negatively impacts on innovativeness by enforcing cultural aspects that do not foster innovation. As a consequence of the unfavourable framework conditions, the propensity to entrepreneurship is low and does not promote innovation activities. This policy and strategy is intended to provide sound framework conditions that will provide appropriate environment for NIS implementation.

This research seeks to answer the following questions:

What is the policy of the government towards innovation in Kenya?

What is the role of government in spurring innovation in Kenya? 


\section{Methodology}

The best way of assessing the strength and weakness of the Kenya National Innovation System is to identify the measurement metrics and use them to estimate the inputs and outcomes of the innovation system. There are inputs that are related to financial aspects of innovation such as $\mathrm{R}$ and $\mathrm{D}$ expenditures as well as aspects to do with human resource engagements. These include $\mathrm{R}$ and $\mathrm{D}$ personnel and tertiary enrolment in Science and Technology fields. There are outputs that are related to the creation aspect of knowledge. These are Science and Technical research publications, patent applications, licensing and trademark applications. Although these inputs and outputs are insufficient and incomprehensive in the assessment of the strengths and weaknesses of the KNIS, but they may provide useful analysis of policy instruments in developing innovation strategies for development. Table 2 below highlights the input and output metrics necessary for measuring the weakness and strengths of KNIS. It also provides a brief description of the significance of each metric in the overall innovation system assessment.

Table 2. Measurement Metrics and their Significance

\begin{tabular}{|c|c|c|}
\hline & Metric & Significance \\
\hline \multirow[t]{4}{*}{ Inputs } & Tertiary Enrolment & $\begin{array}{l}\text { Indicates the number of trained personnel } \\
\text { and the capacity to do research and } \\
\text { innovate }\end{array}$ \\
\hline & $\mathrm{R}$ and $\mathrm{D}$ Expenditure & $\begin{array}{l}\text { Capital expenditures (both public and } \\
\text { private) on creative work undertaken } \\
\text { systematically that improve knowledge } \\
\text { accumulation and its use in new } \\
\text { application development. }\end{array}$ \\
\hline & Researchers in R and D & $\begin{array}{l}\text { Professionals engaged in the conception or } \\
\text { creation of new knowledge, products, } \\
\text { processes, methods, or systems and in the } \\
\text { management of the projects concerned. }\end{array}$ \\
\hline & $\begin{array}{l}\text { Expenditure in } \\
\text { Education }\end{array}$ & $\begin{array}{l}\text { Public spending in education to increase } \\
\text { the capacity to innovate }\end{array}$ \\
\hline \multirow[t]{3}{*}{ Outputs/Outcomes } & Patent Applications & $\begin{array}{l}\text { Indicates domestic inventive activities } \\
\text { undertaken }\end{array}$ \\
\hline & $\begin{array}{l}\text { Trade Mark } \\
\text { Applications }\end{array}$ & Measures business activity engagement \\
\hline & $\begin{array}{l}\text { Science and Technology } \\
\text { Journal Publications }\end{array}$ & $\begin{array}{l}\text { Represents the knowledge base under } \\
\text { which innovative activities depend }\end{array}$ \\
\hline
\end{tabular}

\section{Results of the study}

Innovation played an important role in the economic prosperity of advanced and industrialized countries. Developing countries such as Kenya therefore, must build capacity for innovation in order to succeed and prosper [18] [5]. Capacity building is critical in alleviating poverty. It can help in creating employment opportunities, growth of SMEs, achievement of Millennium Development Goals and increase agricultural production [19] [20]. Kenya can improve capacity building by increasing the amount of GDP expenditure in Research and Development (R and D) in order to increase tertiary enrolment and the number of researchers.

\section{Education and research}

$\mathrm{R}$ and D Expenditure in Kenya was 0.4 percent of GDP in 2007 and 0.8 percent of GDP in 2010. Although this represented an increase of $121.22 \%$ over a period of three years, this is still very low compared with an average of 2.5 per cent of GDP in OECD countries [21]. 
Researchers in R and D are professionals engaged in the creation or conception of new knowledge, products, processes, methods, or systems and in the management and implementation of projects. Statistics show that there were $56.5 \mathrm{R}$ and $\mathrm{D}$ researchers per million population in 2007 and $230.7 \mathrm{R}$ and $\mathrm{D}$ researchers per million population in 2010 in Kenya. This represented an increase of 308.23 percent over 3 years. Increase in R and D personnel implies an increase in capacity to conduct $\mathrm{R}$ and $\mathrm{D}$ and may imply growth in $\mathrm{R}$ and $\mathrm{D}$ output. The number of $\mathrm{R}$ and $\mathrm{D}$ researchers and scientists in Kenya is just about 30 per cent of the level in other developing countries and 2 per cent of the level in OECD countries [22].

Tertiary enrolment ratio is the total enrollment in tertiary education expressed as a percentage of the total population. Figure 4A below shows the trend in tertiary enrolment in Kenya from 1981 to 2009. Although this enrolment has been steady since 1981 from 0.9 percent to 4 percent, this is still low compared with the average of 23 per cent in other developing countries and 57 per cent in high-income OECD countries [20].

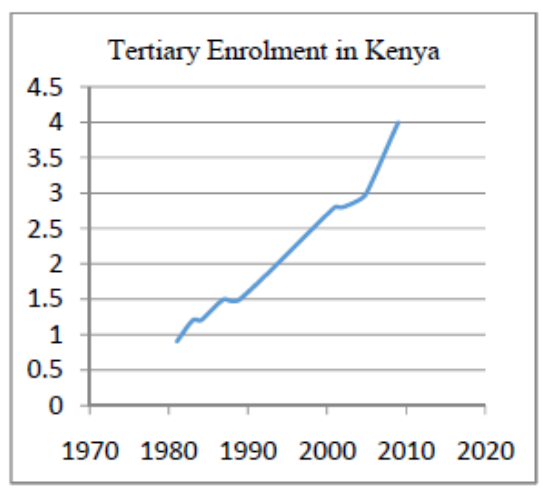

Figure 4A. Tertiary Enrolment in Kenya

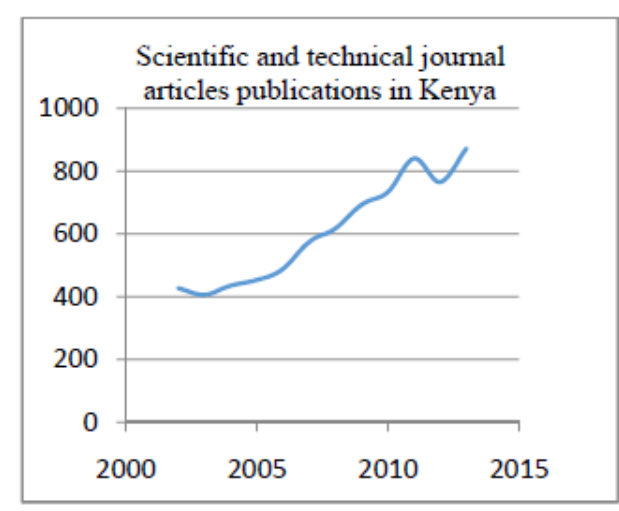

Figure 4B. Scientific and Technical Journal Article Publication

Scientific and technical journal articles imply the number of engineering and scientific articles that were published. Scientific publications are an indicator that represents the knowledge base on which technological activities depend [20]. Figure 4B above shows a positive trend in scientific and technical journal publications in the last few years. It is therefore critical to justify this development. In order to assess the relationship between fixed broadband subscriptions and Scientific and technical journal articles publications, a structural model was developed using regression analysis. Examining this structural model, reveals a path coefficient beta weight $(\beta)$ taking a value of +0.0003 . This coefficient illustrates the strength of the relationship between fixed broadband subscriptions and Scientific and technical journal articles publications. Although this is a weak relationship, it shows a positive trend. The model also computes $R^{2}$. This value shows the amount of variance explained by the independent variable. Both of this measurement constructs and the path coefficients indicate how well the model is performing. The $R^{2}$ value shows the predictive 
power of the model which should be interpreted in the same way as $R^{2}$ in any regression analysis [23] suggesting that the path coefficients should be significant and consistent with expectations. Figure 5 below shows the regression model that is used to analyse the relationship between broadband subscriptions and scientific and technical journal article publications.

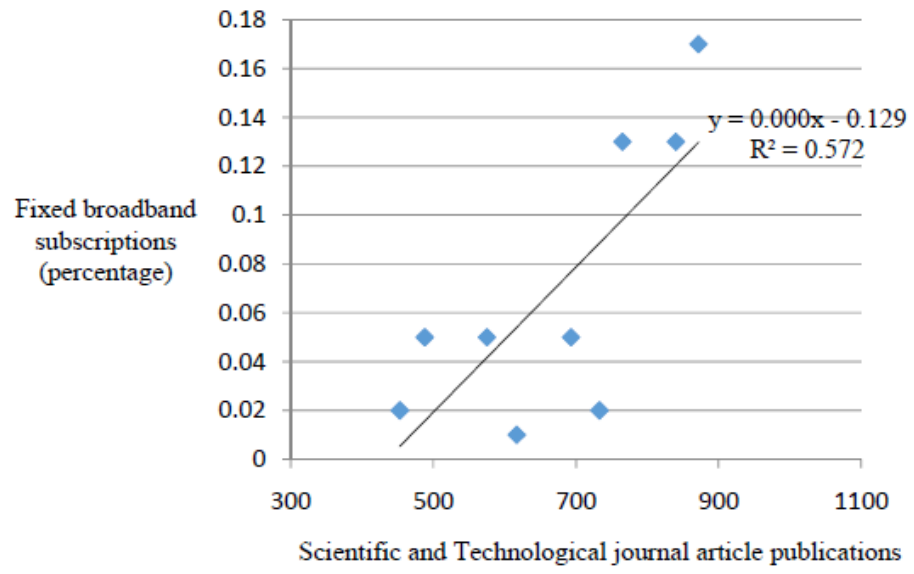

Figure 5. Relationship between Scientific and Technical Journal Article publication and fixed broadband subscriptions

\section{Intermediate organizations (Tech hubs)}

Tech hubs in the form of business incubators and start-up accelerators have been very instrumental in creating and supporting small and medium enterprises (SMEs) in Kenya. They systemizes and accelerates successful enterprise creation process by providing space, support services, clustering and networking opportunities. They nurture and assist new and small businesses through early stages of development leaving them financially stable and selfsupporting. This is achieved by providing administrative services, business advice services such as training, coaching, mentoring and counselling, access to expensive technical equipment, raising finance, and networking between clients and linkage to a wider business community. Some even offer other services such as loan acquisition, venture capital funds and lobbying for special services and help many SMEs in Africa overcome specific business and operational problems... There are currently about 117 active tech hubs in Africa mostly run by foundations, NGOs, developer consortiums or private firms unaffiliated with either government or academic institutions [24]. Tech hubs have been instrumental in the growth of SMEs and start-up companies operating in Africa which are the greatest source of income and employment in Africa. Kenya has about 27 active tech hubs among them; ihub, GrowthHub, Nailab and C4D Lab that have contributed immensely in growth of new and small enterprises in Kenya. Figure 6A below shows the number of active Tech Hubs operating in Africa. Five countries namely; South Africa, Nigeria, Kenya, Egypt and Morocco account for 50\% of active Tech Hubs operating in Africa. 
Texila International Journal of Clinical Research

Volume 4, Issue 1, Dec 2016

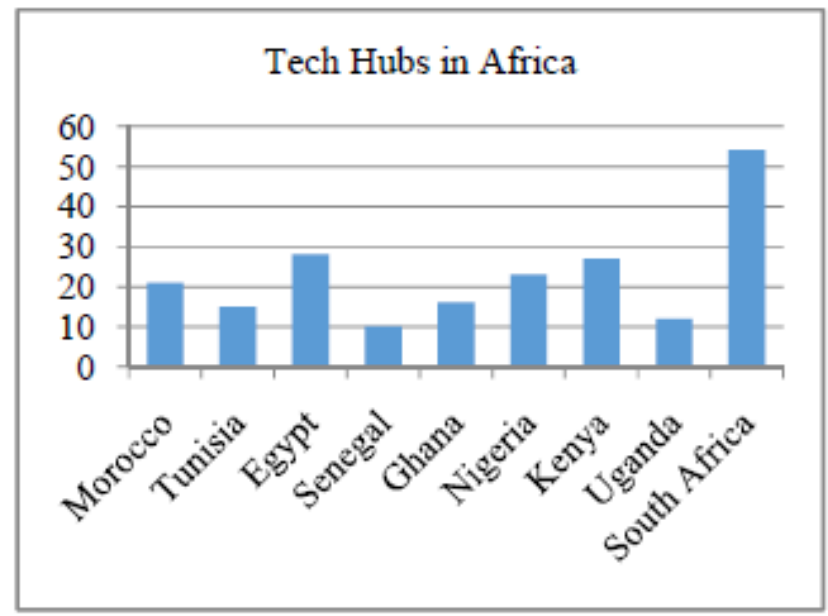

Figure 6A. Tech Hubs in Africa

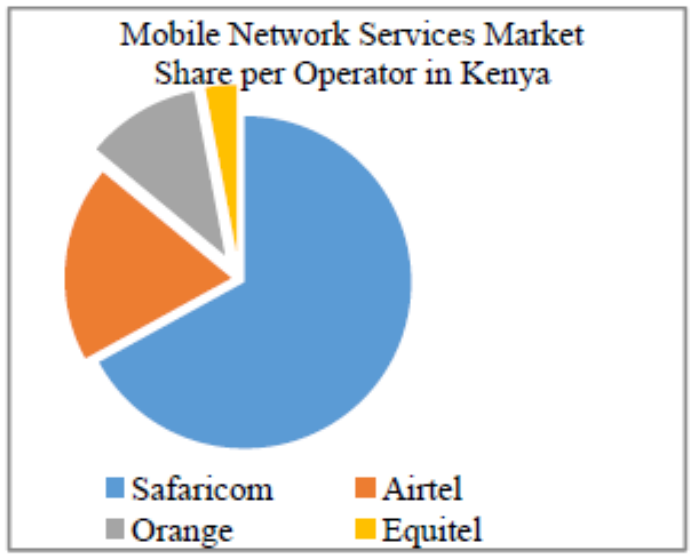

Figure 6B. Mobile Network Market Share

A search in the internet produced about 200 such start-ups operating in Kenya. Although most of them are mobile based applications relying on broadband for smooth functioning, they mainly concentrate in marketing and advertising, electronic business transactions, electronic learning and mobile tools development. This is shown in figure 7 below. Very few deal in farming, health, and transport which are the main pillars of development. Table 3 below summarizes the start-ups that are active in Kenya for the last 10 years by category.

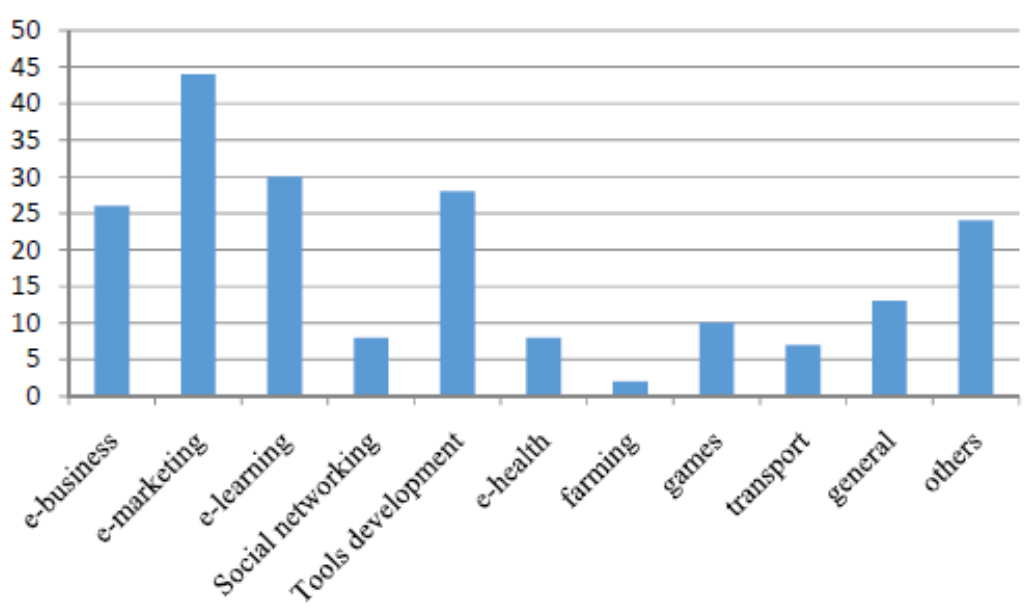

Figure 7. Start-ups in Kenya by Sector 
Table 3. Start-ups in Kenya by Category

\begin{tabular}{|c|c|c|}
\hline Name of Start-up & Category & Description \\
\hline $\begin{array}{l}\text { Ushahidi, SemaTime, } \\
\text { Tujuane }\end{array}$ & $\begin{array}{l}\text { Social } \\
\text { Networks }\end{array}$ & $\begin{array}{l}\text { Develop software for information collection, } \\
\text { visualization and interaction mapping. Social } \\
\text { Networking. provision of SMS based services to } \\
\text { schools, churches }\end{array}$ \\
\hline $\begin{array}{l}\text { PesaPal, M-Kesho, } \\
\text { Kopo kopo, iPay, } \\
\text { Lipisha, Mchanga, } \\
\text { CrowdPesa, Essacco }\end{array}$ & e-business & $\begin{array}{l}\text { A buying and selling payment platform on the } \\
\text { Internet using M-Pesa, Zap and Credit Cards. } \\
\text { enable small and medium businesses acquire } \\
\text { loan. Microfinance Management Solution. } \\
\text { Enable M-Pesa users to open and operate a bank } \\
\text { account. }\end{array}$ \\
\hline $\begin{array}{l}\text { Rupu Kenya, Soko } \\
\text { huru, Shopsoko, } \\
\text { WanaSoko, Mzoori, } \\
\text { Savo Store }\end{array}$ & e-Marketing & $\begin{array}{l}\text { marketing resources for small and large } \\
\text { enterprises, market place that connects buyers } \\
\text { and sellers. online platform to buy, sell, and trade } \\
\text { with your Friends. shopping and package } \\
\text { delivery service }\end{array}$ \\
\hline Ma3Route, E-ticket & e-Transport & share/access info about transport \\
\hline M-Farm & Agriculture & $\begin{array}{l}\text { software solution and agribusiness company } \\
\text { provide agricultural information to farmers. } \\
\text { Provides farmers with real time information } \\
\text { about market prices and where they can sell } \\
\text { produce and buy supplies. }\end{array}$ \\
\hline $\begin{array}{l}\text { Educational Platform, } \\
\text { eLimu, ChuoKikuu }\end{array}$ & e-Learning & $\begin{array}{l}\text { Educational content provision and learning } \\
\text { process. }\end{array}$ \\
\hline KejaHunt & $\begin{array}{l}\text { Property } \\
\text { Management }\end{array}$ & $\begin{array}{l}\text { property listings platform. Kejahunt helps you } \\
\text { find houses, in an easy and credible manner. }\end{array}$ \\
\hline $\begin{array}{l}\text { TrueHost Kenya, } \\
\text { Tech Savvy, Synacor }\end{array}$ & $\begin{array}{l}\text { Tools } \\
\text { Development }\end{array}$ & $\begin{array}{l}\text { providing best domain registration. is home to; } \\
\text { Technology enthusiasts, Technophiles, Hackers, } \\
\text { Coders, Designers, Analysts. }\end{array}$ \\
\hline $\begin{array}{l}\text { Jooist, University of } \\
\text { Games }\end{array}$ & e-gaming & $\begin{array}{l}\text { Enables users to discover games as well as play } \\
\text { using wifi. }\end{array}$ \\
\hline Penda Health & e-Health & $\begin{array}{l}\text { Provides high-quality, affordable, outpatient } \\
\text { healthcare through a chain of health clinic. }\end{array}$ \\
\hline
\end{tabular}

In the last ten years, Kenya has witnessed a steady increase in the number of individuals, SMEs as well as multinational organizations starting business in the country. This is evident from the number of trade mark application and licenses granted over this period. There has also been a steady growth in the number of innovations witnessed over this period. Figure 8A and $8 \mathrm{~B}$ shows a sharp increase in the number of trade mark applications and patents applications. 
Texila International Journal of Clinical Research

Volume 4, Issue 1, Dec 2016

Trade mark Applications by Residents

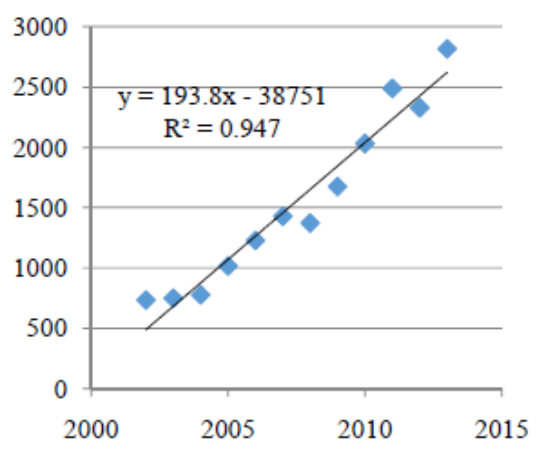

Figure 8A. Trade Mark Applications

Patent applications by residents

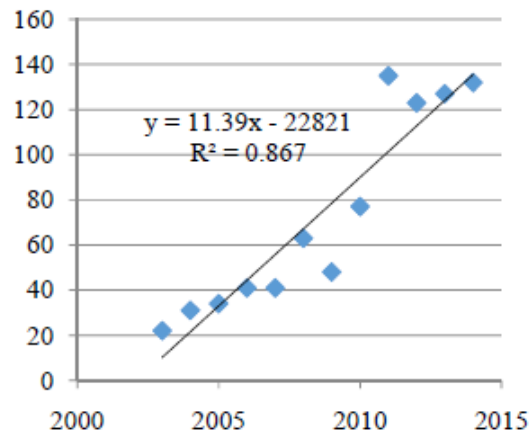

Figure 8B. Patent Applications

In order to assess the relationship between fixed broadband subscriptions and trade mark applications, a structural model was developed using regression analysis. This is represented in figure 9 below. The structural model can be assessed by examining the path coefficients beta weight $(\beta)$ which illustrates the strength of the relationships between the dependent and independent variables. This value is shown as +36.349 indicating a positive strong relationship between fixed broadband subscriptions and trade mark applications. The model also computes the $\left(R^{2}=0.7638\right)$ value. This value shows the amount of variance explained by the independent variable. Both of this measurement construct and the path coefficients indicate how well the model is performing. The $R^{2}$ value shows the predictive power of the model which should be interpreted in the same way as $R^{2}$ in any regression analysis [23] suggesting that the path coefficients should be significant and consistent with expectations.

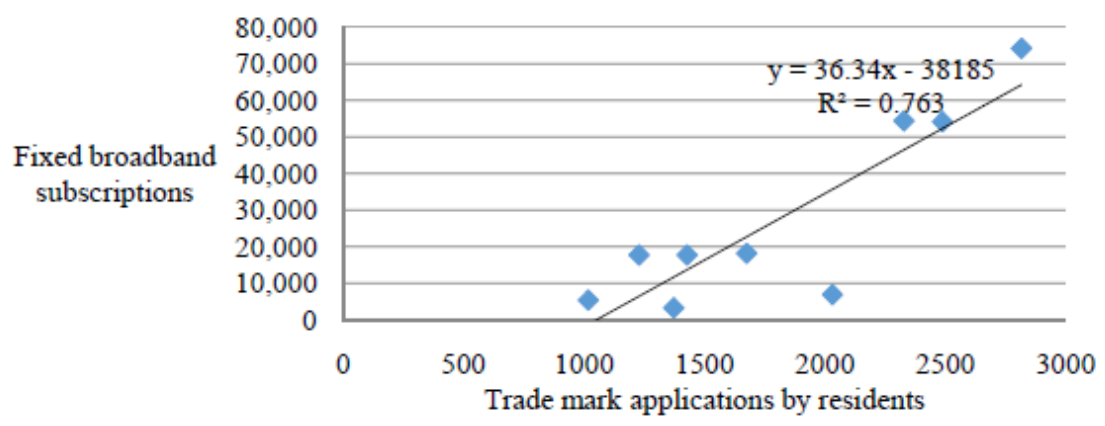

Figure 9: Relationship Between Fixed Broadband Subscriptions and Trade Mark Applications

The number of patents registered by the residents of a country provides some measure of the "success" of expenditures in science and technology and specifically R and D. Patent 
registrations are a critical measure of domestic inventive activity in a country [25]. Patent applications are filed through the Patent Cooperation Treaty procedure or with a national patent office. For this measurement metric, a structural model was developed to assess the relationship between fixed broadband subscriptions and the number of patent applications in Kenya. Figure 10 below indicates this relationship. The path coefficients beta weight ( $\beta$ ) had a value equal to +439.76 . This represents a very strong relationship between fixed broadband subscriptions and the number of patent applications in Kenya. The $R^{2}=0.7788$ value indicates a very strong predictive power of the model.

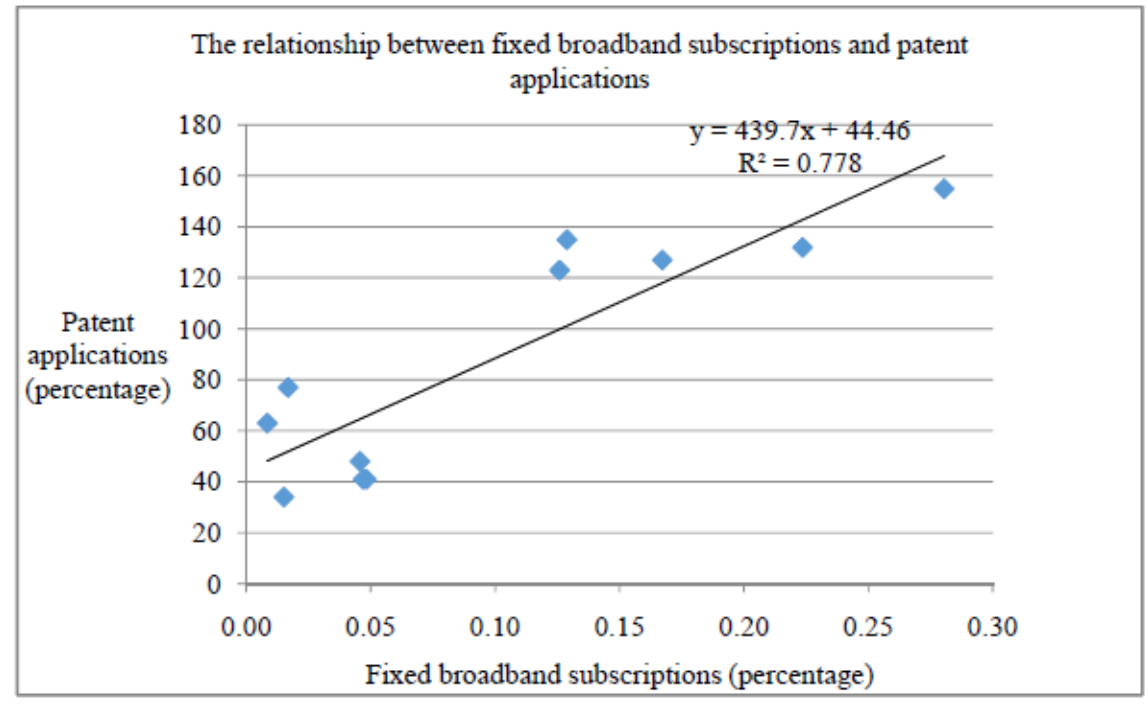

Figure 10. Relationship between Fixed Broadband Subscriptions and Patent Applications

\section{Demand and competition}

Broadband competition in Kenya is between major telecommunications providers and between telecommunications technologies as per the data provided in annual report for the financial year 2014-2015[26]. Figure 6B shows major telecommunications providers competing in the Kenyan market and their market share. The effect of competition is to encourage increase in download speeds and lower price charges per Mbps. This enables broadband penetration and innovative ways of doing business. The main telecommunications providers in Kenya are Safaricom, Orange Kenya, Telecom Kenya, Access Kenya and Zuku. Table 5 below shows the technology they use, their download speeds in Mbps, their monthly charges and the price per Mbps. Competing broadband technologies in Kenya include DSL, Satellite, Fibre, Mobile and Wimax. The last few years has seen a decline in satellite broadband subscriptions and a sharp increase in mobile broadband subscriptions. The table 4 below represents the number of broadband subscriptions in each financial year by each of this technologies.

Table 4. Broadband Subscriptions

\begin{tabular}{|l|l|l|l|l|l|}
\hline \multicolumn{5}{|l|}{ Number of Broadband Subscriptions } \\
\hline Financial Year & $2010 / 11$ & $2011 / 12$ & $2012 / 13$ & $2013 / 14$ & $2014 / 15$ \\
\hline $\begin{array}{l}\text { Fixed Broadband(DSL, } \\
\text { Satellite and Fibre }\end{array}$ & 6,552 & 35,265 & 64,850 & 73,404 & 94,769 \\
\hline Wireless(WIMAX) & 5,646 & 17,282 & 18,634 & 16,959 & 17,103 \\
\hline Mobile & 108,928 & 674,255 & $1,313,339$ & $2,999,794$ & $5,215,987$ \\
\hline Total & 121,126 & 726,802 & $1,398,823$ & $3,090,156$ & $5,327,859$ \\
\hline
\end{tabular}

Source: Communications Authority of Kenya, (2016). Annual Report for the Financial Year 2014-2015 
Texila International Journal of Clinical Research

Volume 4, Issue 1, Dec 2016

Table 5. Broadband Competition by Technology

\begin{tabular}{|l|l|l|l|l|l|}
\hline Operator & Technology & $\begin{array}{l}\text { Download } \\
\text { speed }\end{array}$ & $\begin{array}{l}\text { Monthly } \\
\text { price(US \$) }\end{array}$ & $\begin{array}{l}\text { Price per } \\
\text { Mbps }\end{array}$ & Comment \\
\hline Orange & AVDO & 3.1 & 11.16 & 4 & Data card \\
\hline $\begin{array}{l}\text { Telecom } \\
\text { Kenya }\end{array}$ & ADSL & 0.256 & 39.36 & 154 & $\begin{array}{l}\text { Includes 30 minutes } \\
\text { per month of free } \\
\text { voice }\end{array}$ \\
\hline Safaricom & HSDPA & 7.2 & 18.74 & 3 & $\begin{array}{l}\text { Price adjusted to } \\
\text { reflect 1GB per month } \\
\text { usage }\end{array}$ \\
\hline Zuku & $\begin{array}{l}\text { Cable } \\
\text { modem }\end{array}$ & 1 & 13.11 & 13 & Limited availability \\
\hline Access & WIMAX & 0.32 & 60.90 & 190 & Guaranteed speed \\
\hline
\end{tabular}

Source: Communications Authority of Kenya, (2016). Annual Report for the Financial Year 2014-2015

\section{Broadband infrastructure}

By July 2015, there were over 36.113 million mobile subscribers and mobile penetration of 80.68 per 100 inhabitants in Kenya, 75.86 percent in Tanzania, 50.37 percent in Uganda, 70.48 percent in Rwanda and 46.22 percent in Burundi [27]. In the same period, there were 45.62 percent of internet users in Kenya, 4.87 percent in Burundi, 5.38 percent in Tanzania, 18.0 percent in Rwanda and 19.22 percent in Uganda. This is a strong indication that Kenya has emerged as a leader in broadband utilization in the east African region. Figures 11 and 12 below summarize this information.

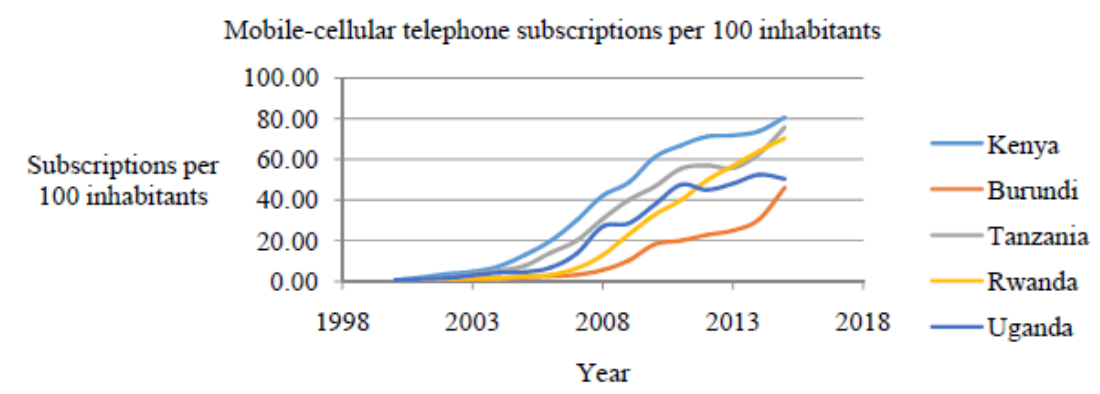

Figure 11. Mobile-cellular Subscriptions in East Africa

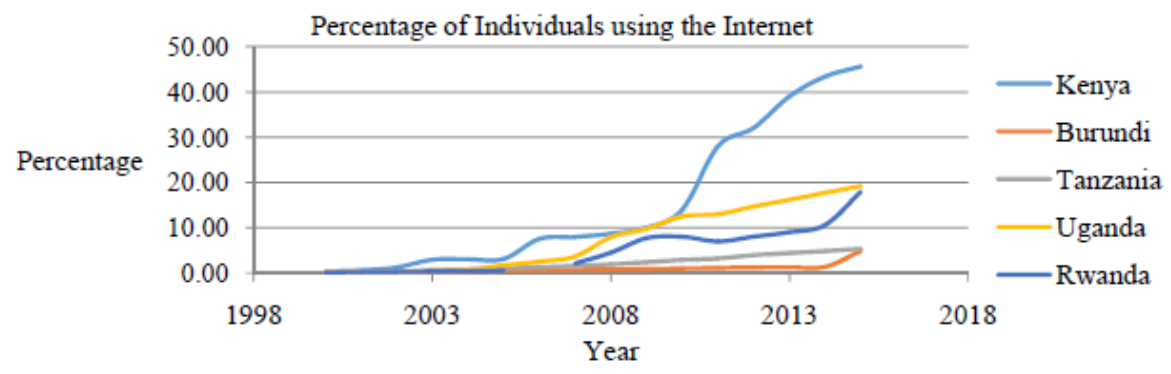

Figure 12. Percentage of Individuals Using the Internet per Country in East Africa

\section{Framework and policy conditions}

Kenya produced its first National ICT Policy in 2006 with a vision of a prosperous ICTdriven Kenyan society. Its mission was to improve the livelihoods of Kenyans by enabling the availability of efficient, reliable and affordable ICT services that are accessible by all. It was guided by the need for policy and regulatory framework, infrastructure development, human resource development and stakeholder participation. The county's information and 
communication regulatory issues are now under the umbrella of the Communication authority of Kenya (CaK) which was formally Communication Commission of Kenya (CCK).

The Government of Kenya has implemented electronic systems in several state Departments and state-owned institutions. These include: the national tax system, the immigration information system, the legal information system, the integrated financial management system and the education system. Furthermore, information is exchanged between departments and institutions e-mail and electronic media. The systems also provide partial electronic services to citizens and businesses through Government portals.

\section{Conclusion and recommendation}

Kenya's growing economy has begun showing skills constraints in technical and critical personnel in various sectors. Investment in high-level technical human resource is low. This is attributed to several reasons. Firstly, education and training does not adequately meet the needs of industry. Many middle colleges have been converted or affiliated to universities to offer degrees with little or no technical experience. Secondly, firms that offer on-the-job training only provide basic operational skills for specific jobs instead of developing technical capacity. Focus on technological learning within industry is required for the exploitation of technologies to enhance competitiveness. Government agencies, multinational organizations as well as local firms operating in Kenya should make use of the local educated labour force. The government can consider temporary special working conditions for their best talent, whether formed at centres of excellence abroad or at home by awarding them contracts and initiatives for investments. Policies should focus on encouraging firm-level innovation through the provision of grants, loans or venture capital for the establishment of in-house research units and/or the hiring of science and technology talent [28]. Training and advice should be provided on the importance of patenting and trade mark protection. This study also recommends a detailed research using current data.

\section{References}

[1]. Annual Report, (2014). Communications Commission of Kenya. CCK, Annual Report December, 2014. retrieved from the website: www.klse.my/financial/annualReport/7035/31-Dec-2014

[2]. Annual Report, (2015). The World bank. Accessed on 12th Sept., 2016 from the website: https://openknowledge.worldbank.org/bitstream/.../WBAnnualReport2015EN.pdf

[3]. Arnold, Erik, and Martin Bell. 2001. Some new ideas about research for development. In Partnerships at the leading edge: A Danish vision for knowledge, research and development, Report of the Commission on Development-Related Research, 279- 316. Copenhagen, Denmark: DANIDA/Ministry of Foreign Affairs.

[4]. Brynjolfsson, Erik \& Saunders, Adam (2010). Wired for Innovation - How Information Technology Is Reshaping the Economy. Cambridge, MA: The MIT Press. Ca 170 pp. https://www.it.uu.se/edu/course/.../ht10/About_Brynjolfsson.pdf

[5]. Chwelos, P., Benbasat, I., Dexter, A.s., 2001. Research report: empirical test of an EDI adoption model. Information System Research 12 (3), 304-321.

[6]. Communications Authority of Kenya, (2016). Annual Report for the Financial Year 2014-2015. Communications Authority of Kenya Annual Report 2016

[7]. de Ferranti, David, Guillermo E. Perry, Indermit Gill, J. Luis Guasch, William F. Maloney, Carolina Sánchez-Páramo, and Norbert Schady. 2003. Closing the gap in education and technology. World Bank Latin American and Caribbean Studies. Washington, D.C.: The World Bank.

[8]. Edison, H., Ali, N.B., \& Torkar, R. (2013). "Towards innovation measurement in the software industry". Journal of Systems and Software 86(5), 1390-407. Available at: http://www.torkar.se/resources/jssedisonNT13.pdf

[9]. Global Innovation Index, (2015). Effective Innovation Policies for Development. Accessed on 10th Sept., 2016 from the website:

https://www.globalinnovationindex.org/userfiles/file/reportpdf/GII-2015-v5.pdf 
Texila International Journal of Clinical Research

Volume 4, Issue 1, Dec 2016

[10]. Global Competitiveness Report, (2015-2016). World Economic Forum. Accessed on 20th Sept., 2016 from the website: https://www.weforum.org/reports

[11]. Hernan Galperin, (2005). Wireless Networks and Rural Development: Opportunities for Latin America. The Massachusetts Institute of Technology Information Technologies and International Development Volume 2, Number 3, Spring 2005, 47- 56. Retrieved from

https://www.itidjournal.org/itid/article/download/204/74

[12]. ITU (2012). Impact of broadband on the economy. Geneva: ITU

[13]. ITU, (2016). ICT Facts and Figures 2016. Found in the website: http://www.itu.int/en/ITUD/Statistics/Pages/facts/default.aspx

[14]. ITU Report, (March 2013). Study on international Internet connectivity in sub- Saharan Africa Retrieved from the website: https://www.itu.int/.../IIC_Africa_Final- en.pdf

[15]. Jerome, L. (2011). Triple helix knowledge clusters, In: M. Saad, G. Zawdie (Eds.), Theory and Practice of Triple Helix Model in Developing Countries, Taylor \& Francis.

[16]. Knell, Mark. 2007. Uneven technological accumulation and growth in the Least Developed Countries. Background Paper No. 11 for UNCTAD's Least Developed Countries Report 2007. Geneva: United Nations Conference on Trade and Development.

[17]. Lazonick, William. 2007. Entrepreneurship, innovation, and development. Paper prepared for United Nations University World Institute for Development Economics Research (UNU-WIDER).

[18]. Metcalfe, Stan., (1995). The economic foundations of technology policy: Equilibrium and evolutionary perspectives. In Handbook of the economics of innovation and technological change, Paul Stoneman. Blackwell Handbooks in Economics, 409-512. Oxford, UK; Cambridge, Mass.: Blackwell.

[19]. Nina Czernich N. and Falck O., (2009). "Broadband Infrastructure and Economic Growth," The Economic Journal, vol. 121, no. 552, pp. 505-532, May 2011. CESifo Working Paper No. 2861. Retrieved from the website: https://www.cesifogroup.de/.../cesifo1_wp2861.pdf

[20]. Science, Technology and Innovation Policy Strategy, (March, 2008). Ministry of Science and Technology. Republic of Kenya accessed on 15th Sept, 2016 from http://www.istafrica.org/home/files/kenya_sti- policy_mar08.pdf

[21]. The Kenya National ICT Master Plan, 2014. ICT Authority of Kenya. Available at: https://www.kenet.or.ke/Master plan 2014.pdf

[22]. Tim Kelly, Rachel Firestone, (2016). How Tech Hubs are helping to Drive Economic Growth in Africa. Background Paper for the World Development Report 2016: Digital Dividends

[23]. Tim Kelly, Rachel Firestone, (2016). How Tech Hubs are helping to Drive Economic Growth in Africa. Background Paper for the World Development Report 2016: Digital Dividends. Found in https://www.ubuntunet.net/sites/default/files/Kelly.pdf

[24]. UNCTAD, (2007). The Least Developed Countries Report 2007: Knowledge, technological learning and innovation for development. Prepared by the United Nations Conference on Trade and Development (UNCTAD) Secretariat. New York and Geneva: United Nations.

[25]. UNCTAD Secretariat. 2004. The role of science and technology in the achievement of the MDGs. Note, Eleventh Session, São Paulo, 13-18 June 2004. United Nations Conference on Trade and Development (UNCTAD).

[26]. UNESCO, (2005). Towards knowledge societies, United Nations Educational, Scientific, and Cultural Organization (UNESCO) World Report. Paris, France: UNESCO Publishing.

[27]. www.knoema.com

[28]. World Economic Forum, “The Global Information Technology Report 2010-2011,” World Economic Forum, 2011. Available online at http://www.weforum.org/reports/globalinformationtechnology-report-2010-2011-0. 